\title{
HIV/AIDS AND OTHER STI IN MEN WHO HAVE SEX WITH MEN - A CONTINUOUS CHALLENGE FOR PUBLIC HEALTH
}

\author{
M J van de Laar (Marita.van.de.Laar@ecdc.europa.eu)1 \\ 1. European Centre for Disease Prevention and Control (ECDC), Stockholm, Sweden
}

This article was published on 26 November 2009.

Citation style for this article: van de Laar MJ. HIV/AIDS and other STI in men who have sex with men - a continuous challenge for public health. Euro Surveill. 2009;14(47):pii=19423. Available online: http://www.eurosurveillance.org/ViewArticle.aspx?ArticleId=19423

World Aids Day provides a good opportunity to take stock of the status of the HIV/AIDS epidemics in Europe and to reflect on achievements made and ongoing challenges. As shown in a rapid communication in this week's special issue of Eurosurveillance, HIV and AIDS remain a threat to public health in the European Union (EU) and the European Economic Area (EEA). Nearly 26,000 newly diagnosed HIV cases were reported for 2008 by the EU and EEA countries [1]. The growing number of new cases of HIV infection presents a burden to public health, health care systems, clinical services and the patients themselves. Over twenty-five years into the epidemic, patterns in Europe have not changed and men who have sex with men (MSM) remain the group most affected. A special issue of Eurosurveillance published on 26 November and 3 December, brings together a number of articles that address the most important issues related to HIV and sexually transmitted infections (STI) in MSM. There is accumulating evidence that the number of newly diagnosed HIV cases among MSM has been increasing in recent years, including recently acquired and acute infection [2].

Monitoring of risk behaviour is of crucial importance for obtaining relevant information on the context of in which HIV transmission occurs. European study by Elford et al. showed that 14 EU/EEA countries had a system for behavioural surveillance among MSM while additional four conducted behavioural surveys or similar studies in this subpopulation [3]. There is a consensus on the use of common main behavioural indicators such as unprotected anal intercourse, condom use, number of partners, HIV testing; while specific indicators vary considerably across countries. These results demonstrate a clear need for harmonisation of methods and indicators to obtain comparable data in Europe.

Monitoring of risk behaviour provides evidence of the effects of specific preventive interventions, especially when this information is collected linked with data on the prevalence of HIV and STI. For instance, the risk reduction strategy used by some MSM to have unprotected anal intercourse with casual partners with known HIV status does present a risk for STI transmission and undoubtedly has contributed to the recent increases of hepatitis $\mathrm{C}$ and STI coinfections among HIV-positive MSM [4-7].

The overall increase in proportion of men who engage in sexual risk behaviour such as unprotected sex with casual partners presented in several articles in this issue is of concern but confirms previous studies from Denmark and the United Kingdom [8-11]. Additional evidence of risk behaviour among MSM follows from a virological study by Cuevas et al. who showed that HIV cases in
MSM could be frequently grouped in large transmission clusters whereas clusters detected in heterosexual patients were mostly two-person clusters [12].

The study by Folch et al. also demonstrates the circumstances in which unprotected anal intercourse is more likely to happen with casual partners. It is associated with the use of different drugs, a large number of sexual partners, the use of the internet to meet sexual partners, and low self-esteem. The authors showed that men who found it difficult to live with their homo/bisexuality were more likely to have unprotected sex with casual partners, putting themselves at risk for STI and HIV [8].

Serosorting can be a strategy to reduce HIV transmission however it also carries an important risk as often the serostatus is assumed. Also, the perception of one's own serostatus may be false, as suggested by Velter et al., as a fraction of the MSM who believe to be HIV-negative could in fact be infected [9]. Serosorting could in fact contribute to the risk of HIV transmission as was shown in other studies as well $[13,14]$.

The use of serosorting was shown to be more prevalent among HIV-negative than among HIV-positive men in France [9]. Serosorting was associated with having less partners and lower level of drug use in HIV-negative men. In HIV-positive men serosorting was associated with the use of the internet to meet sexual partners and was less frequent among those who used cruising venues. The internet is a relatively new tool for MSM to meet sexual partners and for researchers to recruit MSM for behavioural surveys. It has proven to be useful for research purposes as large sample sizes at relatively low costs can be obtained in the context of a lacking proper sampling frame for MSM. The disadvantage is that samples recruited via the internet may not be representative for the MSM population and tend to overestimate the true risk of STI and HIV in the population [3].

A study in six cities in Southern and Eastern Europe shows that the HIV prevalence rates range between $17 \%$ in Barcelona, $5 \%$ in Bucharest and Ljubljana, and $3 \%$ in Prague. The low prevalence in Eastern European cities is encouraging; however, the Mirandola et al also report a high level of risk behaviour and lower frequency of HIV test seeking behaviour, suggesting that there is a clear potential for increased HIV transmission [15]. HIV testing is an important indicator of the health care system's ability to reach MSM and to efficiently provide access to screening. In their study a lower access in Eastern European cities is reported as compared with Southern European cities. Maintaining lower levels of HIV 
among MSM require continued preventive efforts. This is also the conclusion of Tripathi et al. who describe high-risk behaviour in MSM and diversity in knowledge on HIV transmission for Estonia, a country with a high prevalence of HIV infection in injecting drug users [16].

Several studies in the Eurosurveillance special issue describe trends in concurrent STI and HIV among men who have sex with men. The number of syphilis cases among MSM has increased considerably in Western European countries in the past decade but Savage et al suggest that MSM in Central Europe are becoming an important risk group as well [17]. This finding is consistent with the report from Slovenia by Klavs et al which describes increasing trends of syphilis and HIV among MSM [18]. An increasing number of lymphogranuloma venereum (LGV) cases has been recently reported by several Western European countries, with close to $80 \%$ of cases being HIV-positive [19]. The slowly evolving LGV epidemic among HIV-positive MSM poses questions regarding risk factors and acquisition of infection.

Increasing trends in HIV among MSM are reported by Sasse and Defraye for Belgium [20], Semaille et al. for France [21], and by Diaz et al. for Spain [22]. Although this could be due to increased HIV testing, it is shown in Belgium that the number of tests has remained stable over time [20]. In France, about 50\% of the newly diagnosed HIV infections in MSM in 2003-2008 were recently infected and high rates of co-infection with syphilis and LGV were reported [21]. On the other hand, data from Belgium and Slovenia show that a considerable proportion of HIV-positive MSM are diagnosed late (CD4 $<200$ or AIDS diagnosed within three months). It is of concern that many HIV diagnoses take place during STI consultation (11\% of the new HIV diagnoses in Belgium). The Belgian authors suggest implementing behavioural surveillance and qualitative research to improve effective prevention campaigns [20]. Similar conditions are described in the paper from Spain which shows high HIV prevalence rates among syphilis patients, highlighting the importance of the availability of information on HIV and STI co-infections, as this is usually not covered by the national surveillance system for HIV and STI [22].

Simultaneous infection with HIV and STI affects the progression and treatment of both HIV and other STI $[23,24]$. Co-infection with hepatitis poses serious clinical complications, HIV/HCV co-infection is associated with lower rates of spontaneous viral clearance, accelerated progression of liver disease and less favourable treatment outcome, as covered in the review by Urbanus et al. [5,24]. The emergence of hepatitis C among HIV-positive MSM is poorly understood; it raises questions in respect to the transmission of hepatitis $C$ which seems to be associated with rough sexual techniques and blood-blood transmission rather than sexual transmission alone $[5,25]$, which is supported by a recent case-control study [26].

Many contributions in this special issue provide evidence that high-risk behaviour is increasing across Europe, HIV transmission is ongoing, increased levels of co-infections are observed and outbreaks of STI continue among MSM. Existing prevention campaigns do not seem sufficient to contain sexual risk behaviours among this group in Europe. Prevention campaigns need to be comprehensive and easy to understand at the same time, address primary prevention (to avoid infection), secondary prevention (to avoid the further spread of infection) and tertiary prevention (to treat the infection and reduce levels of viral load). HIV prevention campaigns promoting regular screening and condom-use should be pursued and limitations of serosorting be highlighted and explained as it exposes both HIV-negative and HIV-positive men to the risk of STI.

More research is needed to better identify the circumstances of HIV and STI transmission in order to optimise target prevention campaigns. The review by Berg shows that, despite the maturity of the HIV epidemic, outcome evaluations of any form of behavioural HIV/STI intervention for MSM in Europe are scarce [27]. Although evidence-based policies and practices are needed to tackle the increasing trends in HIV/AIDS and STI, little research is carried out to evaluate the effectiveness of interventions in MSM

\section{References}

1. Van de Laar MJ, Likatavicius G. HIV and AIDS in the European Union, 2008. Euro Surveill. 2009;14(47):pii=19422. Available from: http://www.eurosurveillance. org/ViewArticle.aspx?ArticleId=19422

2. Sullivan PS, Hamouda O, Delpech V, Geduld JE, Prejean J, Semaille C, et al. Reemergence of the HIV epidemic among men who have sex with men in North America, Western Europe, and Australia, 1996-2005. Ann Epidemiol. 2009;19(6):423-31.

3. Elford J, Jeannin A, Spencer B, Gervasoni JP, van de Laar MJ, Dubois-Arber F, et al. HIV and STI behavioural surveillance among men who have sex with men in Europe. Euro Surveill. 2009;14(47):pii=19414. Available from: http:// www.eurosurveillance.org/ViewArticle.aspx?ArticleId=19414

4. Götz HM, van Doornum G, Niesters HG, den Hollander JG, Thio HB, de Zwart 0. A cluster of acute hepatitis $C$ virus infection among men who have sex with men--results from contact tracing and public health implications. AIDS. 2005;19(9):969-74.

5. Urbanus AT, van de Laar TJ, Stolte IG, Schinkel J, Heijman T, Coutinho RA, et al. Hepatitis $C$ virus infections among HIV-infected men who have sex with men: an expanding epidemic. AIDS. 2009;23(12):F1-7.

6. Dougan S, Evans BG, Elford J. Sexually transmitted infections in Western Europe among HIV-positive men who have sex with men. Sex Transm Dis. 2007;34(10):783-90.

7. Van de Laar MJ. The emergence of LGV in Western Europe: what do we know, what can we do? Euro Surveill. 2006;11(9):pii=641. Available from: http://www. eurosurveillance.org/ViewArticle.aspx?ArticleId=641

8. Folch C, Muñoz R, Zaragoza K, Casabona J. Sexual risk behaviour and its determinants among men who have sex with men in Catalonia, Spain. Euro Surveill. 2009;14(47):pii=19415. Available from: http://www.eurosurveillance. org/ViewArticle.aspx?ArticleId=19415

9. Velter A, Bouyssou-Michel A, Arnaud A, Semaille C. Do men who have sex with men use serosorting with casual partners in France? Results of a nationwide survey (ANRS-EN17-Presse Gay 2004). Euro Surveill. 2009;14(47):pij=19416. Available from: http://www.eurosurveillance.org/ ViewArticle.aspx?ArticleId $=19416$

10. Cowan SA, Haff J. HIV and risk behaviour among men who have sex with men in Denmark - the 2006 Sex Life Survey. Euro Surveill. 2008;13(48):pij=19050. Available from: http://www.eurosurveillance.org/ViewArticle. aspx?ArticleId $=19050$

11. Elford J, Bolding G, Davis M, Sherr L, Hart G. Trends in sexual behaviour among London homosexual men 1998-2003: implications for HIV prevention and sexual health promotion. Sex Transm Infect. 2004;80(6):451-4.

12. Cuevas MT, Fernández-García A, Sánchez-García A, González-Galeano M, Pinilla M, Sánchez-Martínez M, et al. Incidence of non-B subtypes of HIV-1 in Galicia, Spain: high frequency and diversity of HIV-1 among men who have sex with men. Euro Surveill. 2009;14(47):pii=19413. Available from: http://www. eurosurveillance.org/ViewArticle.aspx?ArticleId=19413

13. Williamson LM, Dodds JP, Mercey DE, Hart GJ, Johnson AM. Sexual risk behaviour and knowledge of HIV status among community samples of gay men in the UK. AIDS. 2008;22(9):1063-70.

14. Eaton LA, Kalichman SC, Cain DN, Cherry C, Stearns HL, Amaral CM, et al. Serosorting sexual partners and risk for HIV among men who have sex with men. Am J Prev Med. 2007;33(6):479-85.

15. Mirandola M, Folch Toda C, Krampac I, Nita I, Stanekova D, Stehlikova D, et al. HIV bio-behavioural survey among men who have sex with men in Barcelona, Bratislava, Bucharest, Ljubljana, Prague and Verona. Euro Surveill. 2009;14(48):pii=19427. Available from: http://www.eurosurveillance.org/ ViewArticle.aspx?ArticleId $=19427$ 
16. Tripathi A, Rüütel K, Parker RD. Correlates of HIV risk behavior knowledge, substance use and unprotected sex in men who have sex with men in Tallinn, Estonia. Euro Surveill. 2009;14(48):pii=19429. Available from: http://www. eurosurveillance.org/ViewArticle. aspx?ArticleId=19429

17. Savage EJ, Hughes G, Ison C, Lowndes CM, the European Surveillance of Sexually Transmitted Infections (ESSTI) network. Syphilis and gonorrhoea in men who have sex with men: a European overview. Euro Surveill. 2009;14(47):pij=19417. Available from: http://www.eurosurveillance.org/ ViewArticle.aspx?ArticleId=19429http://www.eurosurveillance.org/ViewArticle. aspx?ArticleId=19417

18. Klavs I, Bergant N, Kastelic Z, Lamut A, Kustec T. Disproportionate and increasing burden of HIV infection among men who have sex with men in Slovenia: surveillance data for 1999-2008. Euro Surveill. 2009;14(47):pii=19419. Available from: http://www.eurosurveillance.org/ViewArticle.aspx?ArticleId=19419

19. Savage EJ, van de Laar MJW, Gallay A, van der Sande M, Hamouda 0 , Sasse $A$, et al. Lymphogranuloma venereum in Europe. Euro Surveill. 2009;14(48):pii=19428. Available from: http://www.eurosurveillance.org/ ViewArticle.aspx?ArticleId $=19428$

20. Sasse A, Defraye A. HIV infections and STI co-infections in men who have sex with men in Belgium: sustained increase in HIV diagnoses. Euro Surveill. 2009;14(47):pii=19420. Available from: http://www.eurosurveillance.org/ ViewArticle.aspx?ArticleId $=19420$

21. Semaille C, Cazein F, Lot F, Pillonel J, Le Vu S, Le Strat Y, et al. Recently acquired HIV infection in men who have sex with men (MSM) in France, 2003-2008. Euro Surveill. 2009;14(48):pij =19425. Available from: http://www. eurosurveillance.org/ViewArticle.aspx?ArticleId $=19425$

22. Diaz A, Junquera ML, Esteban V, Martínez B, Pueyo I, Suárez J, et al. HIV/ STI co-infection among men who have sex with men in Spain. Eur Surveill. 2009;14(48):pii=19426. Available from: http://www.eurosurveillance.org/ ViewArticle.aspx?ArticleId $=19426$

23. Hill C, McKinney E, Lowndes CM, Munro H, Murphy G, Parry JV, et al. Epidemiology of herpes simplex virus types 2 and 1 amongst men who have sex with men attending sexual health clinics in England and Wales: implications for HIV prevention and management . Euro Surveill. 2009;14(47):pij=19418. Available online: http://www.eurosurveillance.org/ViewArticle.aspx?ArticleId=19418

24. Urbanus AT, van Houdt R, van de Laar TJ, Coutinho RA. Viral hepatitis among men who have sex with men, epidemiology and public health consequences. Euro Surveill. 2009;14(47):pii=19421. Available from: http://www.eurosurveillance. org/ViewArticle.aspx?ArticleId=19421

25. Götz HM, van Doornum G, Niesters HG, den Hollander JG, Thio HB, de Zwart 0 . A cluster of acute hepatitis $C$ virus infection among men who have sex with men--results from contact tracing and public health implications. AIDS. 2005;19(9):969-74.

26. Danta M, Brown D, Bhagani S, Pybus OG, Sabin CA, Nelson M, et al. Recent epidemic of acute hepatitis $C$ virus in HIV-positive men who have sex with men linked to high-risk sexual behaviours. AIDS. 2007;21(8):983-91.

27. Berg RG. The effectiveness of behavioural and psychosocial HIV/STI prevention interventions for MSM in Europe: A systematic review. Euro Surveill. 2009;14(48):pii=19430. Available from: http://www.eurosurveillance.org/ ViewArticle.aspx?ArticleId $=19430$ 